with matters for which they are intended, yet might be quite meaningless when applied outside their legitimate limits. Thus it is possible, and indeed probable, that many of the questions propounded might be really quite meaningless; and therefore it is unlikely that any sensible answers can be found for them. It was here that Mr. Carington urged the more extensive use of a mathematical type of language in which the symbols employed do not suggest any relationships other than those deliberately assigned to them. In conclusion, Mr. Carington briefly referred to his recent studies of trance personalities, where, through statistical methods, a clearer understanding is being achieved and light is being thrown on the problem as to how these secondary or multiple personalities differ or not from other communicating personalities, which operate through the so-called mediumistic trance.

\section{Air Mask to Protect Workers}

As air mask which will provide the rock driller, painter or chemical worker_with fresh air and protect him from poisonous gases, smoke and dust is described in a recent report by Science Service, of Washington, D.C. The mask is literally a film or curtain of air completely covering the user's face but leaving the eyes, nose and mouth free. When it is intended for use as the conventional gas mask, the new mask is a shield similar to an eye shade and worn on the forehead. The visor of the shield con. trins an air chamber, provided with numerous out. wardly slanting openings at its lower edge. When air under pressure is forced into the chamber, streams of air issue outwardly and downwards from the openings, and form a transparent air screen or curtain completely covering the face but at some distance from it. With this air film for protection, the user could pass through dust, smoke, gas or paint fumes without any of them coming in contact with his face. The inventor also claims that there would be no trouble in breathing, the air curtain furnishing a continual supply of fresh air.

\section{The New Guinea Agricultural Gazette}

THE editors of the New Guinea Agricultural Gazette are to be congratulated on the first number $(1$, No. 1 , October 1935. Pp. 50. Rabaul : Department of Agriculture) containing articles on the cultivation or marketing of five crops of economic importance to New Guinea, besides others on entomology and meteorology. The appearance of the journal is another indication of the indispensability of at least a little science to every planter or agriculturist. Many of the most isolated countries in the world now issue semi-scientific agricultural periodicals which, since they can scarcely be financially profitable, must be produced in response to a demand for knowledge. The Agricultural Gazette shows that the New Guinea planters and Agricultural Department are fully alive to the fact that science is as necessary to the prosperity of a small colony as of a highly developed country.

\section{Fruit Tree Pests}

THE classification of insects by the damage they cause is not, perhaps, scientific, but is of great practical use to the gardener. Mr. G. Fox Wilson outlines such a classification of fruit tree pests (J. Roy. Hort. Soc., December 1935). Feeding habits of different types of fruit tree pests are discussed, and the structure of the mouth parts is considered in relation to their effects on the plant. The work of Nierenstein on gall formation is passed under review, and the effects of 'honeydew' are discussed. Very little new knowledge is contained in the paper; its main value lies in the eonvenience of its outlook from a horticultural point of view.

\section{News Value of Science}

IN an address to the Georgia Press Institute and the Henry W. Grady School of Journalisnı, University of Georgia, on February 19, Mr. Watson Davis, director of Science Service, discussing the news value of science, suggested that though we have largely left the stage in which the man of science was regarded as a mysterious being or magician, possessed of powers for good or ill, and regarded him as a person who could provide us with many of the wonders of our daily life, we have yet to reach the stage in which science is regarded as a guide for personal conduct and political affairs. That will come as fast as education in the scientific habit of thinking, particularly through the Press, allows it to come. Great improvements have been witnessed in the fifteen years since Science Service was first formed for the reporting and interpretation of science, and the cooperation established in this way between journalists and men of science in the United States has already had very valuable results. Science is receiving much more serious attention from the daily Press, and already a number of science editors are on the staffs of American newspapers. The combination of journalistic ability and scientific attainment which is essential in a good interpreter is, however, not easy to find, and Mr. Davis also emphasised the danger which the very popularisation of science may offer to the maintenance of scientific standards. Inaccuracy must not be the price of more effective distribution of scientific knowledge to the public.

\section{Freezing of Niagara Falls}

From the office of the High Commissioner for Canada a special bulletin has been received dealing with the freezing of Niagara Falls. This was prepared by Mr. G. H. Wood, assistant engineer, Dominion Water Power and Hydrometric Bureau, Department of the Interior, Ottawa, and states that the American falls became completely frozen over on January 25 this year and remained so at least up to the date of the bulletin (February 20), a length of time never previously recorded. Freezing was rare in the early days before the diversion of much of the water for power purposes and the present low cycle of discharge from Lake Erie, and did not occur once between the earliest recorded occasion in 1848 and the next occasion on February 14, 1909. It appears that there 
is no record of the Canadian falls (Horseshoe falls) having ever been frozen over; but the channel leading to the American falis is shallow and carries only five per cent of the flow over the cascades, and, becoming obstructed by ice at times, may then be frozen over. Such an event is always due to ice jams at the head of Goat Island, which occur when thick ice on Lake Erie is broken up by strong southwesterly gales, and large quantities of floe ice are driven into the Niagara River and carried downstream. The level of Lake Erie is stated to be close to its minimum recorded level, and the discharge of the river very low in consequence. The comparative frequency with which the falls have been frozen over (for a short time) since 1922 is clearly, therefore, no evidence for an increase in the average severity of American winters ; in fact, temperature records show just the reverse in spite of the occurrence of a few isolated spells of unusual cold within the last few years.

Determination of Hydrogen Ion Concentration of Soils

The British Drug Houses have recently brought out a new type of soil-testing outfit for determination of $p \mathrm{H}$ values, in which barium sulphate is used as a clarifying agent. This enables the determination to be made with a greater degree of precision than has hitherto been possible, particularly in the case of clay soils. The outfit has been designed in response to a persistent demand for means of estimating $p \mathrm{H}$ values conveniently and accurately in the field, and is fitted up in a compact oak cabinet of readily portable form. The cost of the complete outfit is fl 1 s., and prices are also quoted in the descriptive pamphlet (issued by British Drug Houses) for the individual items, should need arise for their replacement.

\section{Directory and Buyers' Guide, 1936-37}

THE Engineer is the oldest and one of the most influential journals in Great Britain dealing with the progress of engineering... In the interests of the firms advertising in the paper, the proprietors publish every two years a useful directory of about 250 pages. The first 38 pages give an index and vocabulary in French, German, Italian and Spanish of the technical words used in the book. The next 156 pages give an alphabetical list of the manufacturers together with their telephone numbers and telegraphic addresses. The next section gives their telegraphic addresses and the codes they use. Finally a carefully selected list is given of the numbers and titles of British Standard Specifications. The guide has been carefully prepared, and should prove useful to consulting engineers and contractors. It is issued free of charge by the proprietors of the Engineer. To qualify for inclusion under appropriate headings, it is necessary to advertise in the columns of the Engineer to the extent of $£ 25$ a year.

\section{The Original Use of the Word "Solute"}

Dr. P. Lecomte DU NoüY, writing from the Institut Pasteur, Paris, asks if it is known who is responsible for the coining of the useful word 'solute'.
The word is not to be found in old text-books, but the "Oxford English Dictionary" gives a quotation from Sir William Dampier's "Recent Developments of Physical Science" in which the word is used in its present sense. Upon referring the point to Sir William, however, he informs us that the Dictionary is wrong in implying that the first use of the word is in that volume, which was first published in 1904. In his "Theory of Solution", published two years earlier, he says (p. 49), "It is eustomary to distinguish between the medium or solvent and the dissolved substance or solute". On the other hand, in his "Solution and Electrolysis", published in 1895, Sir William uses the word 'solvend' instead of 'solute'. Apparently, therefore, the word 'solute' was introduced between 1895 and 1902, but who was respon. sible for the coining of it remains undecided. Perhaps some of our readers can throw light upon the question.

\section{Heavy Water and the Colour of Hydrated Salts}

IN connexion with his communication on the influence of heavy water on the colour of hydrated salts (NATuRE, March 28, p. 534), Dr. James Bell writes that it appears that the observation that copper sulphate pentadeuterate solutions and crystals are more green in tint than those of the pentahydrate had already been made. H. Perpérot and F. Schacherl, in an account of an investigation of the vapour ten. sions of the different deuterates of copper sulphate (J. de Physique et le Radium, vii, 6, 439; Oct. 1935), mention this difference in colour, and state that they have undertaken an examination of the absorption spectra of the solutions. As it is unusual for work on this field to be published in that journal, and an abstract has not yet been available, this paper was inadvertently overlooked.

\section{Award of Goethe Medal}

Ir is announced that Herr Hitler has conferred the Goethe Medal on Dr. Max Uhle, of Berlin. Dr. Uhle, who is an honorary fellow of the Royal Anthropological Institute, has a world-wide reputation as one of the foremost authorities on South American archæology. During a residence there of many years he explored a large number of prehistoric sites in Peru, some of his work in the field being supported by grants from the Phoebe B. Hearst benefaction of the University of California. His studies, more particularly of the pottery, are the basis of generally accepted views on the character and chronology of Pre-Inca civilisation.

\section{International Association on Quaternary Research}

THE third International Conference of the International Association on Quaternary Research will be held in Vienna, on September 1-7. After the con. ference, excursions will be made to the East Austrian Alps and their forelands. These excursions will start on September 9 and continue until September 25. Those who propose to attend the conference and excursions should write at once for further details and approximate cost to the president, Prof. Dr. Albrecht Penck, c/o Inqua, Rasumofskygasse 23, Vienna III, Austria. 